\title{
FORTHCOMING ISSUE
}

It is hoped to publish in the next issue of the Proceedings of The Nutrition Society reports of symposia on Problems in Providing Rations for Britain's Livestock (1 and 2 October 1953) and on The Provisioning of Expeditions in the Field (26 October 1953). 
CONTENTS OF VOLUME 12, No. 3, 1953

(All rights reserved)

\title{
SYMPOSIUM PROCEEDINGS
}

\author{
Eighty-first Scientific Meeting
}

LIND BICENTENARY SYMPOSIUM

A CONFERENCE ON SCURVY AND VITAMIN C IN HONOUR OF JAMES LIND, M.D., F.R.C.P.E., WHOSE Treatise of the Scurvy WAS PUBLISHED IN EDINBURGH, A.D. 1753

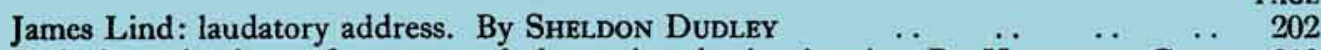

Early investigations of scurvy and the antiscorbutic vitamin. By HARRIETTE CHICK 210

The discovery and chemistry of vitamin C. By CHARLES GLEN KING $\quad \ldots \quad$. $\quad 219$

The occurrence of vitamin C in foods. By M. van EEkrLen . $\quad \begin{array}{llllll} & \ldots & \ldots & \ldots & 219\end{array}$

Chairman's opening address: James Lind. By A. INGLEBY-MACKENZIE $\quad \begin{array}{lllll}\cdots & \ldots & 233\end{array}$

The Sheffield experiment on the vitamin $\mathrm{C}$ requirement of human adults. By H. A.

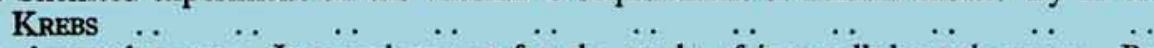

Experimental scurvy. Its employment for the study of intercellular substances. By

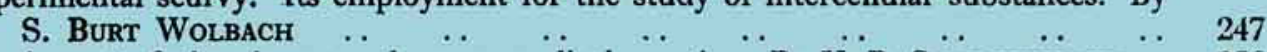

The impact of vitamin research upon medical practice. By V. P. SYDENSTRICKER $\ldots \quad 256$

Presidential address: The Nutrition Society of Britain, the first 12 years. By R. C.

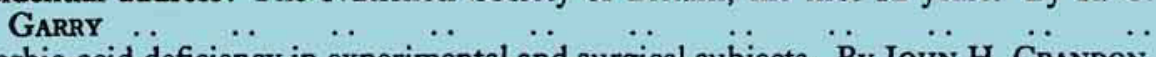

Ascorbic-acid deficiency in experimental and surgical subjects. By JoHN H. CRANDON, Stanley Mikal and Bernard R. LANDEAU $\ldots$

Ascorbic acid in relation to cold, scurvy, ACTH and surgery. By RoBert M. KARK
Aminoaciduria in infancy and ascorbic-acid deficiency. By J. P. DustrN and E. J. $\begin{array}{lllllllllllll}\text { BIGWOOD } & \ldots & \ldots & \ldots & \ldots & \ldots & \ldots & \ldots & \ldots & \ldots & \ldots\end{array}$

Dehydroascorbic acid in human blood plasma. By C. $\ddot{\mathrm{P}}$. Strewart, $\ddot{\mathrm{D}} . \mathrm{B}$. Horn and

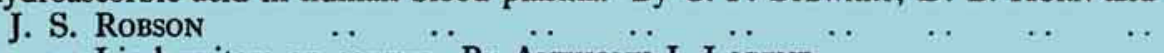

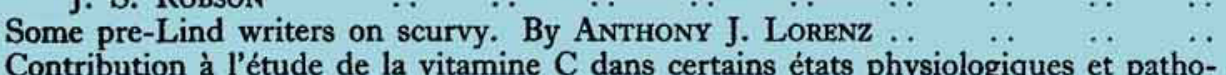

Contribution à l'étude de la vitamine $\mathrm{C}$ dans certains états physiologiques et patho-
logiques chez l'homme. Par Hugues Gounklle et Henri Teulon ..

Ascorbic acid, pteroylglutamates, and other factors in scorbutic hydroxyphenyluria. By William J. Darby, William J. McGanity, Anne Stockell and Calvin

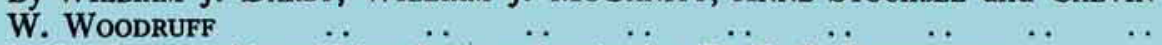

Synthesis of $\mathrm{L}$-ascorbic acid in plants and animals. By F. A. Istrerwoon ...

The enzymic conversion of $\mathrm{L}$-galactono- $\gamma$-lactone to $\mathrm{L}$-ascorbic acid by plant mito-

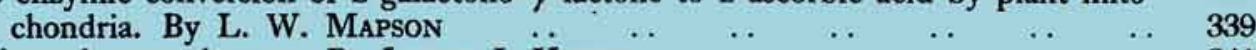

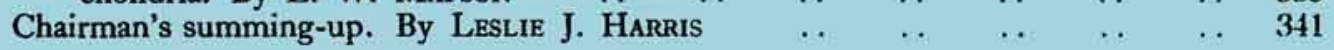

\section{INDEX OF AUTHORS}

\begin{tabular}{|c|c|c|c|}
\hline Bigwood, E. J. & .. & $\cdots$ & .. \\
\hline Chick, H. . & . & $\cdots$ & \\
\hline $\begin{array}{l}\text { Crandon, J. H. } \\
\text { Darby. W. I. }\end{array}$ & & $\begin{array}{l}\cdots \\
\ldots\end{array}$ & . \\
\hline Dudley, S. & $\begin{array}{l}\cdots \\
\cdots\end{array}$ & $\begin{array}{l}\cdots \\
\cdots\end{array}$ & . \\
\hline Dustin, J. P. & . & .. & .. \\
\hline Garry, R. C. & $\ldots$ & .. & . \\
\hline Gounelle, H. & . & .. & . \\
\hline Harris, L. J. & .. & . & . \\
\hline Horn, D. B. & . & $\cdots$ & . \\
\hline Ingleby-Mackenz & ie, $\mathrm{A}$. & . & \\
\hline Kark R M & & & \\
\hline King, C. G. & 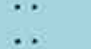 & .. & $\begin{array}{l}\cdots \\
\cdots\end{array}$ \\
\hline
\end{tabular}

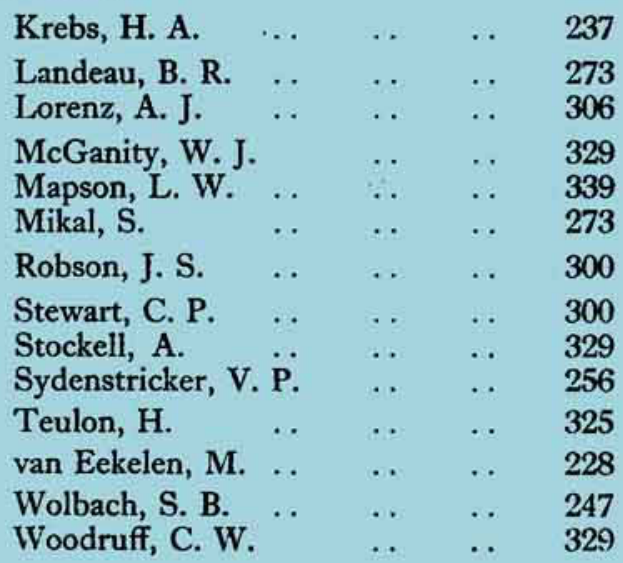

